\title{
EVALUATIONS OF 105-K REACTOR BUILDING FLOOR SLAB FREQUENCIES AND BASEMAT STRESSES (U)
}

by R. L. Bandyopadhyay

Westinghouse Savannah River Company

WSRC-RP- $-90-1328$

Savannah River Site

Aiken, South Carolina 29808

Other Authors:

This paper was prepared in connection with work done under Contract No. DE-AC09-89SR18035 with the U. S. Department of Energy. By acceptance of this paper, the publisher and/or recipient acknowledges the U.S. Government's right to retain a nonexclisive, royalty-free license in and to any copyright covering this paper, along with the right to reproduce and to authorize others to rep roduce all or part of the copyrighted paper.
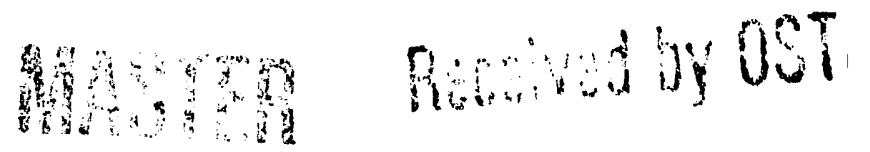


\section{DISCLAIMER}

This report was prepared as an account of work sponsored by an agency of the United States Government. Neither the United States Government nor any agency thereof, nor any of their employees, makes any warranty, express or implied, or assumes any legal liability or responsibility for the accuracy, completeness, or usefulness of any information, apparatus, product, or process disclosed, or represents that its use would not infringe privately owned rights. Reference herein to any specific commercial product, process, or service by trade name, trademark, manufacturer, or otherwise does not necessarily constitute or imply its endorsement, recommendation, or favoring by the United States Government or any agency thereof. The views and opinions of authors expressed herein do not necessarily state or reflect those of the United States Government or any agency thereof.

This report has been reproduced directly from the best available copy.

Available to DOE and DOE contractors from the Office of Scientific and Technical Information, P.O. Box 62, Oak Ridge, TN 37831; prices available from (615) 576-8401, FTS 626-8401.

Available to the public trom the National Technical Information Service, U.S. Department of Commerce, 5285 Port Royal Rd, Springfield, VA 22161. 
$W S K C-K P-90-1328$

\section{EVALUATIONS OF 105-K REACTOR BUILDING FLOOR SLAB FREQUENCIES AND BASEMAT STRESSES (U)}

\section{DECEMBER, 1990}

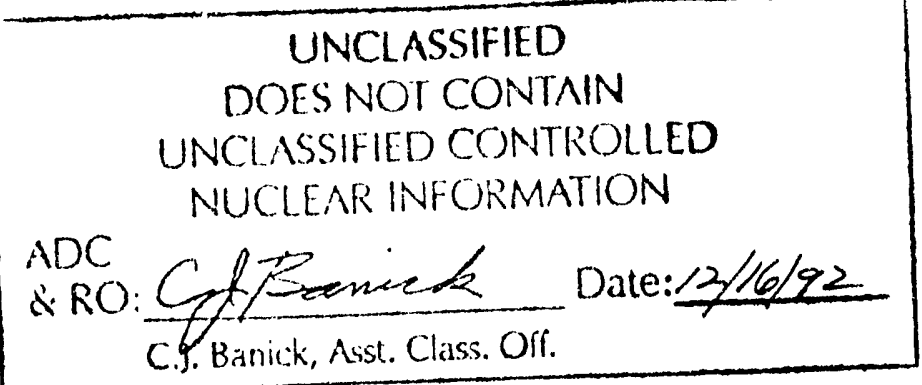

PREPARED

APPROVED

$R L$ Bandyopadkyay $12 / 90$

R. L. Bandyopadhyay, Group Leader

Seismic Structural Engineering

APPROVED

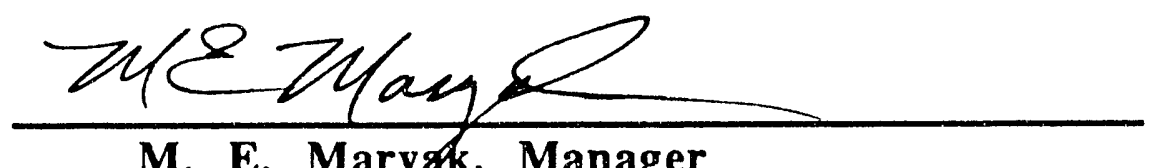

M. E. Maryak, Manager

Seismic Structural Engineering

APPROVED

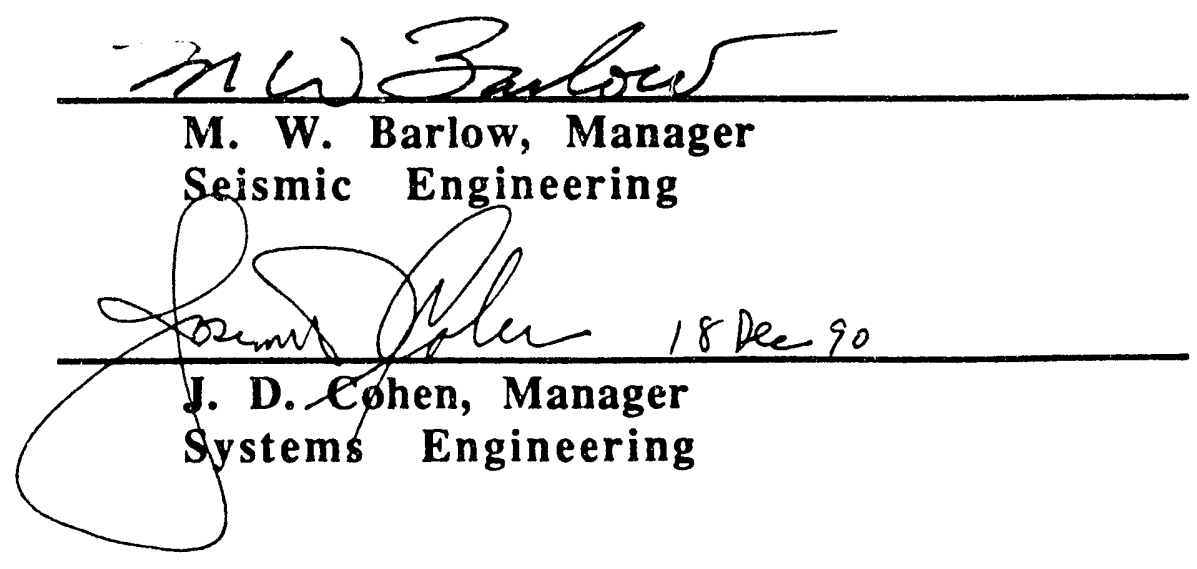


W SR C - R P - 90 - 1328

EVALUATIONS OF 105-K REACTOR BUILDING FLOOR SLAB FREQUENCIES AND BASEMAT STRESSES (U)

DECEMBER， 1990

SEISMIC STRUCTURAL ENGINEERING

TASK FORCE

R. L. Bandyopadhyay

R. C. Chen

J. S. Mulliken 
WESTINGHOUSE SAVAMNAH RIVER COMPANY

E\&PD SYSTEMS ENGINEERING DEPARTMENT

SEISHIC STRUCTURAL ENGINEERING

105-K REACTOR SLAB FREQUENCIES \& BASEMAT STRESSES
USRC-RN- $90-1328$

REVISION 0

DECEMBER, 1990

PAGE 1 OF 14

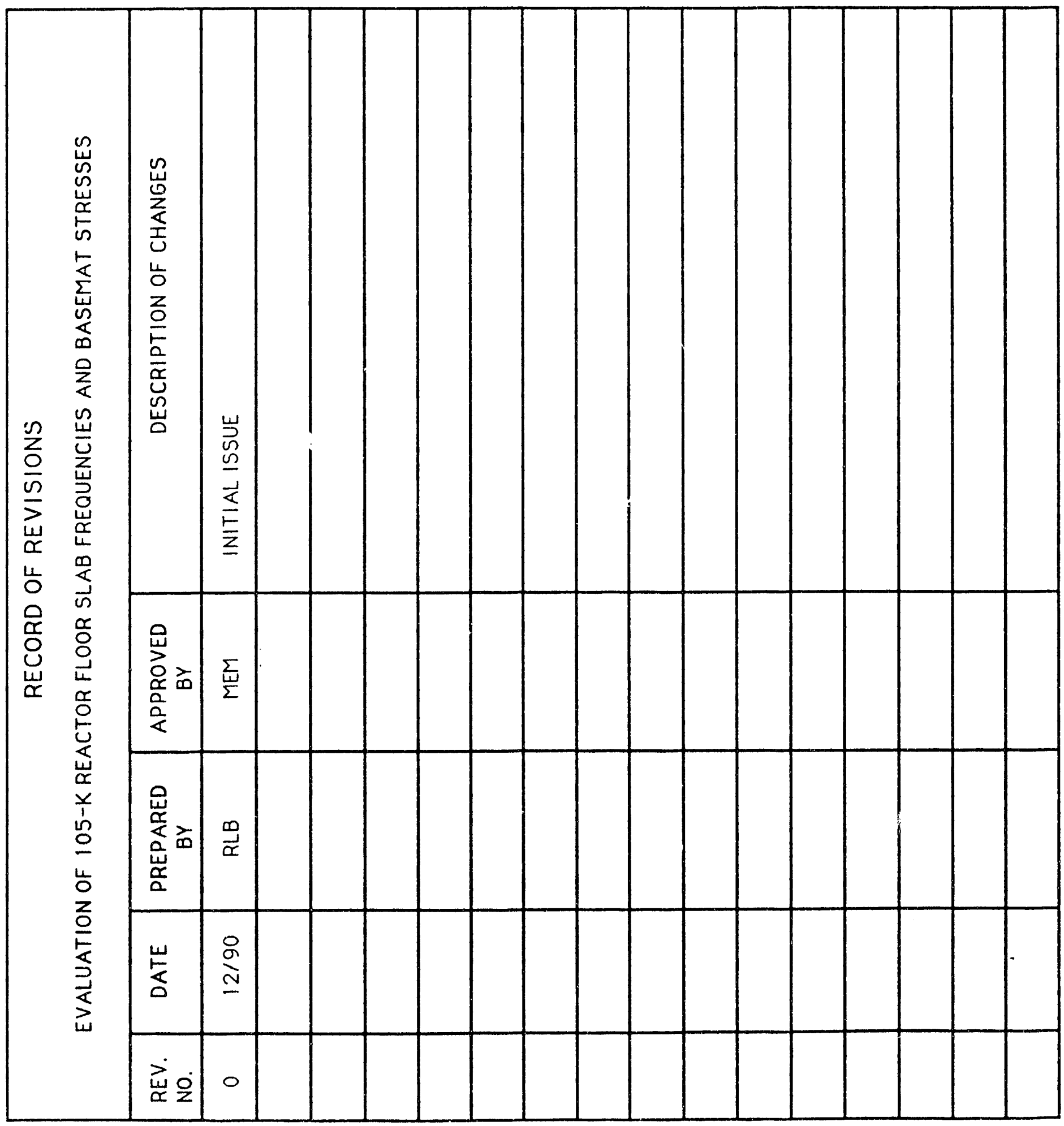




\section{TABLE OF CONTENTS}

1.0 objective

2.0 Description of Procedures

2.1 Frequency Calculation 3

2.1.1 Slab Dimensions 3

2.1.2 Boundary Conditions 4

2.1.3 Loads 4

2.1.4 Aspect Ratio 4

2.1.5 Analysis 5

2.1.6 Computer Program 6

2.1 .7 Discussion of Results 6

2.2 Basemat Stresses 9

2.2.1 Codes and Standards 9

2.2.2 Assumptions 10

2.2.3 Parameters 11

2.2.4 Evaluation 11

3.0 Conclusion 12

3.1 Frequency 12

3.2 Basemat Evaluation 12

4.0 References 13 


\subsection{OBJECTIVE}

This report describes the evaluation of natural frequencies of the concrete floor slabs in the $\mathrm{K}$ Reactor. The evaluation of the floor frequencies at elevation 34 ft and below is required to demonstrate that the floor frequencies of the Reactor Building are sufficiently high. This will provide confidence in the interim position that the structural amplification of the vertical motion are approximately in the same order or less than the structural amplification of the horizontal motion. Consequently, this evaluation determines the acceptability of using horizontal floor response spectra or two thirds of the horizontal floor response, on a case by case basis, as an interim estimate of the vertical motions in the $\mathrm{K}$ Reactor for restart.

Basemat stresses in the Process area are also tabulated in this report. Both evaluations are required for Reactor Restart.

\subsection{DESCRIPTION OF PROCEDURES}

\subsection{FREQUENCY CALCULATION}

The frequency of a slab depends on various parameters. These parameters are discussed below.

\subsubsection{BLAB DIYENBIONB}

All pertinent information was collected from the drawings for the $\mathrm{K}$ Reactor Process Building. 


\subsubsection{BOUNDARY CONDITIONS}

All boundary conditions were taken from the drawings. The drawings were carefully examined and the boundary conditions for the slabs were classified as simply supported, fixed or continuous. In addition all the reinforcement details were checked at the fixed or continuous edges to verify adequate lap lengths. Where lap lengths were not sufficient or sufficient dowels were not provided, the edges were taken as simply supported.

\section{$\underline{2.1 .3 \quad \text { LOADS }}$}

For dead loads, the weight of concrete is taken as 150 $1 \mathrm{bs} / \mathrm{ft}^{3}$. Live load is assumed to be $100 \mathrm{lbs} / \mathrm{ft}^{2}$ in the operating floors and $40 \mathrm{lbs} / \mathrm{ft}^{2}$ on the roof area (EL 27.5 ft and EL $34.0 \mathrm{ft}$ ).

\subsubsection{ASPECT RATIO}

Aspect ratio is the ratio between the long span and the short span of a slab and determines whether a slab is acting as one way slab or two way slab. All the drawings were examined in detail to determine the aspect ratios from slab dimensions. If this ratio was two or greater, the slab was considered one way, otherwise two way slab was considered. The reinforcement details, lap lengths, dowels etc. were examined to verify the one way/two way slab configuration. 


\subsubsection{ANALYSIS}

The frequency for a one way slab is given by:

$$
\text { frequency }=\frac{1.2769}{2 \pi} \sqrt{\frac{g}{8}}
$$

(Reference 1)

where :

$$
\begin{aligned}
& \delta=\text { maximum deflection for the slab } \\
& g=\text { acceleration due to gravity }
\end{aligned}
$$

Therefore the maximum deflection for each slab must also be calculated. This was performed using the deflection formulas in the beam section of the AISC manual (Ref 2).

Frequency for a two way slab was calculated by the following equation :

$$
\text { frequency }-\frac{\lambda^{2}}{2 \pi a^{2}} \sqrt{\frac{E h^{3}}{12 \gamma\left(1-v^{2}\right)}}
$$

(Reference 3)

where:

$\lambda=$ dimensionless frequency parameter determined by boundary conditions using table 11-4 of reference 3

$a=$ appropriate span length determined by the boundary conditions and geometry using table 11.4 of reference 3 .

$E=$ modulus of elasticity

$\gamma=$ mass per unit area

$\mathrm{h}=$ thickness of slab

$v=$ poission's ratio with consistency of units in accordance with table 3-1, page 10 of ref 3 . 


\subsubsection{COMPUTER PROGRAM}

A FORTRAN program (Ref 4) was written to calculate the natural frequency of the concrete slabs using the above two equations. A formatted input file containing reference nodes, thicknesses, spans, and boundary conditions must be specified to run the program. This information is used to perform a one way or two way slab analysis, whichever is appropriate according to the data given in the input file. Two output files containing information for each slab such as elevations, reference nodes, thickness, span, corresponding support conditions, and frequency will result from the computer run. One of the output files will list all slabs and corresponding information that were analyzed by one way analysis, and the other will contain slabs which were analyzed as two way slabs.

The computer program was verified by alternate calculations for various slabs, taken at random. A sample of the output is shown on page 14 .

\section{1 .7 DIBCU8BION OF REBULTS}

A total of 64 slab segments were considered. The following table shows the summary of the results.

Frequency

No. of slab segments

Percentage

$>33 \mathrm{~Hz}$

$>20 \mathrm{~Hz}$

$>16 \mathrm{~Hz}$
76.6

90.6

95.3 
Slab locations and frequencies are shown below :

$\begin{array}{lll}\text { Location } & \text { No. of slab segments } & \text { Frequency Range } \\ -20.0 \mathrm{ft} & 16 & 57 \text { to } 1489 \mathrm{hz} \\ 0.0 \mathrm{ft} & 25 & 66 \mathrm{to} 641 \mathrm{hz} \\ & & 1 \mathrm{seg} \text { e } 24 \mathrm{hz} \\ 15.0 \mathrm{ft} & 8 & 25 \mathrm{to} 175 \mathrm{hz} \\ 16.0 \mathrm{ft} & 1 & 1 \mathrm{seg} \cdot \mathrm{e} 16.25 \mathrm{hz} \\ 21.0 \mathrm{ft} & 1 & 20 \mathrm{hz} \\ 26.33 \mathrm{ft} & 4 & 33 \mathrm{hz} \\ 27.5 \mathrm{ft} & 1 & 21,28,31,74 \mathrm{hz} \\ 34.0 \mathrm{ft} & 8 & 14.33 \mathrm{hz}\end{array}$

A comparison of the horizontal and vertical SSI modes (see references 7 and 8 ) show that they are both about $2.5 \mathrm{hz}$. The radiation damping for both directions of motion is also expected to be comparable. The fundamental horizontal fixed base frequency of the $\mathrm{K}$ Reactor is $6.9 \mathrm{hz}$, and the second mode frequency is $12.47 \mathrm{hz}$. The fundamental vertical fixed base mode of the Reactor is about $18 \mathrm{hz}$, which represents the global dynamic behavior determined by the mass of the building and the vertical frequency of the walls. The lowest out-ofplane slab frequency below elevation $0.0 \mathrm{ft}$ is above $33 \mathrm{hz}$. 
It may be postulated that the amplifications due to SSI modes will be similar for the horizontal and vertical directions of motion. This will result in vertical floor response spectra at the base of the dynamic model (elev. $-20.0 \mathrm{ft}$ ) that are approximately two third of the horizontal floor response spectra, with the spectral amplifications centered primarily in the frequency range of $2.5 \mathrm{hz}$. Floor response spectra amplifications between elevations $-20.0 \mathrm{ft}$ and $0.0 \mathrm{ft}$ are expected to be less than amplifications in the horizontal direction because the separation of SSI and fixed base building frequencies is wider in the vertical direction than in the horizontal direction. Based on this reasoning, the verticis floor response spectra below elevation $0.0 \mathrm{ft}$ are expected to be about two-thirds of the horizontal floor response spectra at comparable elevations.

Most of the equipment to be seismically qualified in the $\mathrm{K}$ Reactor are below elevation $0.0 \mathrm{ft}$. However, there are a few pieces of equipment which are at elevations $15 \mathrm{ft}$ and $34 \mathrm{ft}$. Most of the floor panels at these elevations have out of plane fundamental frequencies of $33 \mathrm{hz}$ or higher. Only three slab segments have frequency less than $16 \mathrm{hz}$ and the frequencies are as follows :

\begin{tabular}{|c|c|c|c|c|}
\hline $\begin{array}{c}\text { Elevation } \\
\text { ft }\end{array}$ & Reference Grid & $\begin{array}{c}\text { Dimension } \\
\mathrm{ft}\end{array}$ & $\begin{array}{c}\text { Thick } \\
\text { in }\end{array}$ & $\begin{array}{c}\text { Freq } \\
\mathrm{hz}\end{array}$ \\
\hline EL 27.50 & $A L-D L / 7-8$ & $34 \times 51$ & 30 & 14.33 \\
\hline EL 34.00 & $\mathrm{BR} / 5-6$ & $54 \times 59$ & 42 & 14.75 \\
\hline EL 34.00 & / 103-1 & $36 \times 37.75$ & 24 & 14.61 \\
\hline
\end{tabular}


These low frequencies resulted from either one of the conditions listed below of "combiarin is them :

a) small thickness of the slabs compared to the spans,

b) simply supported boundary condition of one or more edges.

The slab a EL $27.50 \mathrm{ft}$ is in the stack building and it has been analyzed and found satisfactory (Ref 5). The other two slabs are roof slabs where no major equipment are located.

It is our considered opinion that significant slab amplifications of vertical motions are not expected at these two elevations, because there is still significant separation between the fundamental out-of-plane slab frequencies and vertical SSI modes. Hence, horizontal floor response spectra at these elevations may be used as an interim estimate of vertical motions for qualification of equipment.

\subsection{BABEYAT BTRESBE8}

The basemat stresses were evaluated for the combined effect of dead, live and seismic loads.

\subsubsection{CODES AND STANDARDB}

ACI 349-85 and ACI 349R-85 : Code Requirements for Nuclear Safety Related Concrete Structures (ACI 349-85) and Commentary - ACI 349R-85, American Concrete Institute, Detroit, Michigan. 


\section{2 .2 A88ONPTIONS}

The evaluation of the basemat is a complex one. For the purpose of this report the following assumptions are made:

A) The Process Building is modelled as a stick model, similar to the stick model for the C Reactor (Ref 6). The $\mathrm{K}$ Reactor is identical to the $\mathrm{C}$ Reactor.

B) The mat - $170 \mathrm{ft} \times 250 \mathrm{ft}$ - is considered $170 \mathrm{ft} \times 170$ ft for simplicity of computation.

C) Dead loads were taken from the report on C Reactor (Ref 6) .

D) Seismic shear forces were taken from the report on $k$ Reactor (Ref 7).

E) An eccentricity of $9 \mathrm{ft}, 5 \%$ of the least dimension of 170 ft, were considered for dead and live loads.

F) Live loads were taken as $100 \mathrm{lbs} / \mathrm{sq} . \mathrm{ft}$.

G) The mat is considered rigid and the maximum bearing pressure is calculated at the end of the basemat.

H) This bearing pressure is then applied to a few critical portions of the base mat. It is emphasized that every slab of the basemat was not analyzed, but only a few critical segments chosen by engineering judgement. This approach is considered conservative as the maximum bearing pressure, which itself was calculated conservatively, is used to evaluate the slabs irrespective of locations. 


\subsubsection{PARAMETERS}

The following design parameters were considered for evaluation:

Allowable concrete stress, $f_{c}^{\prime}=2,500 \mathrm{psi}$

Allowable steel stress, $\quad f_{t}=40,000 \mathrm{psi}$

The reinforcement details and slab thicknesses were taken from the $\mathrm{K}$ reactor drawings.

\subsubsection{EVALUATION}

The most critical of the load combinations of $1.4 \mathrm{DL}+$ 1.7LL or $\mathrm{DL}+\mathrm{LL}+\mathrm{SE}$ were considered for the design. The base mat thickness varies from $8 \mathrm{ft}$. to $10 \mathrm{ft}$. and the minimum thickness of $8.0 \mathrm{ft}$. was considered for the evaluation. In the critical sections, shear reinforcement in the form of stirrups have been used, and where appropriate, strengths of shear reinforsements have been considered for shear capacities.

The critical Demand/Capacity ratio is given below :

$$
\begin{array}{ll}
\text { Moment, } D / C & =0.87 \\
\text { Shear, } D / C & =0.86
\end{array}
$$




\subsection{CONCLUSION}

\subsection{FREQUENCY}

The frequencies of three segments out of a total of 64 segments fall below $16 \mathrm{hz}$. One segment is in the stack building, while the other two are roof area, and no major equipment is mounted there. Based on this evaluation, it may be concluded that the floor slabs will behave in a rigid-like manner and structural amplifications of the vertical motion will be no larger than the structural amplifications of the horizontal motion and horizontal floor response spectra are a conservative estimate of the vertical floor response spectra ir the $K$ Reactor. building.

\subsection{BABEYAT EVALUATION}

The Demand-Capacity ratios, by very conservative calculation, are well under 1.0 and therefore quite adequate to resist dead, live, and seismic forces. 


\subsection{REFERENCES}

1. Roark, Raymond J. and Young, Warren C. : Formulas for Stress and strain, Fifth Edition, McGraw-Hill.

2. Manual of Steel Construction, American Institute of steel Construction, Chicago.

3. Blevins, Robert D. : Formulas for Natural Frequency and Mode Shape, Van Nostrand Reinhold.

4. Calculation no., S-CLC-K-00014: Evaluation of $105 \mathrm{~K}$ Reactor Building Floor slab Frequencies and Base Mat Stresses.

5. URS / John A. Blume \& Associates : Phases I, II and III of the Comprehensive Seismic Analysis and Evaluation of the 105K Exhaust stack Building at the Savannah River Site, December, 1989.

6. John A. Blume \& Associates : Seismic Analysis of Buildings $105 \mathrm{C}$ and $105 \mathrm{R}$ and associated systerns and equipment of the Savannah River Plant, Vol II, January, 1969.

7. URS / John A. Blume \& Associates : Floor Acceleration Response Spectra for Updated DBE and Reg. Guide 1.60 Seismic Input : Building 105K, Savannah-River Plant.

8. EQE Engineering : Seismic Analysis of The Vertical Tube Storage system Monorail support Frames in Building 105-L, 105-K, and 105-P at The Savannah River Plant ; Soil-structure Interaction Analyses of Buildings 105- L, 105-K and 105-P; September 1989 . 


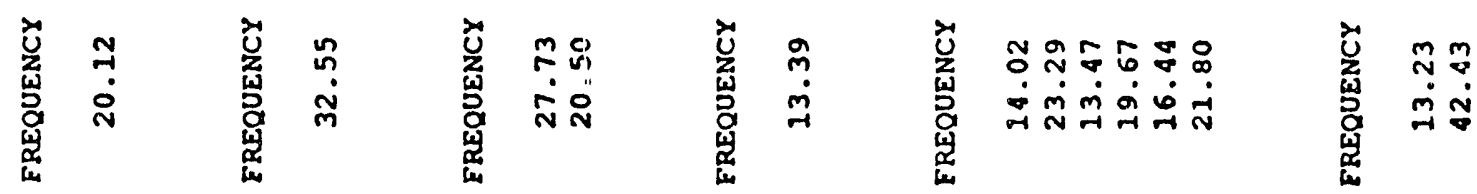
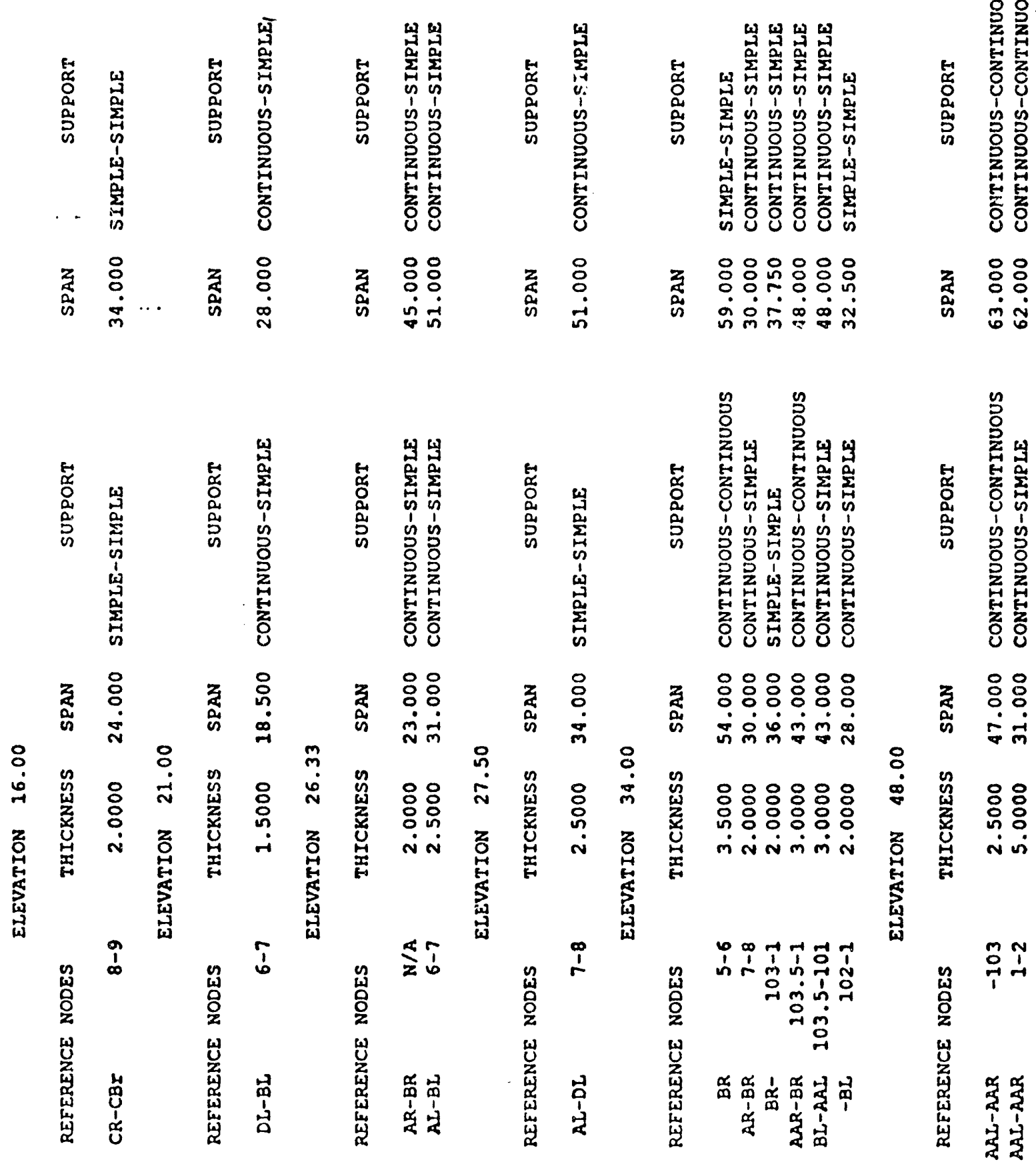

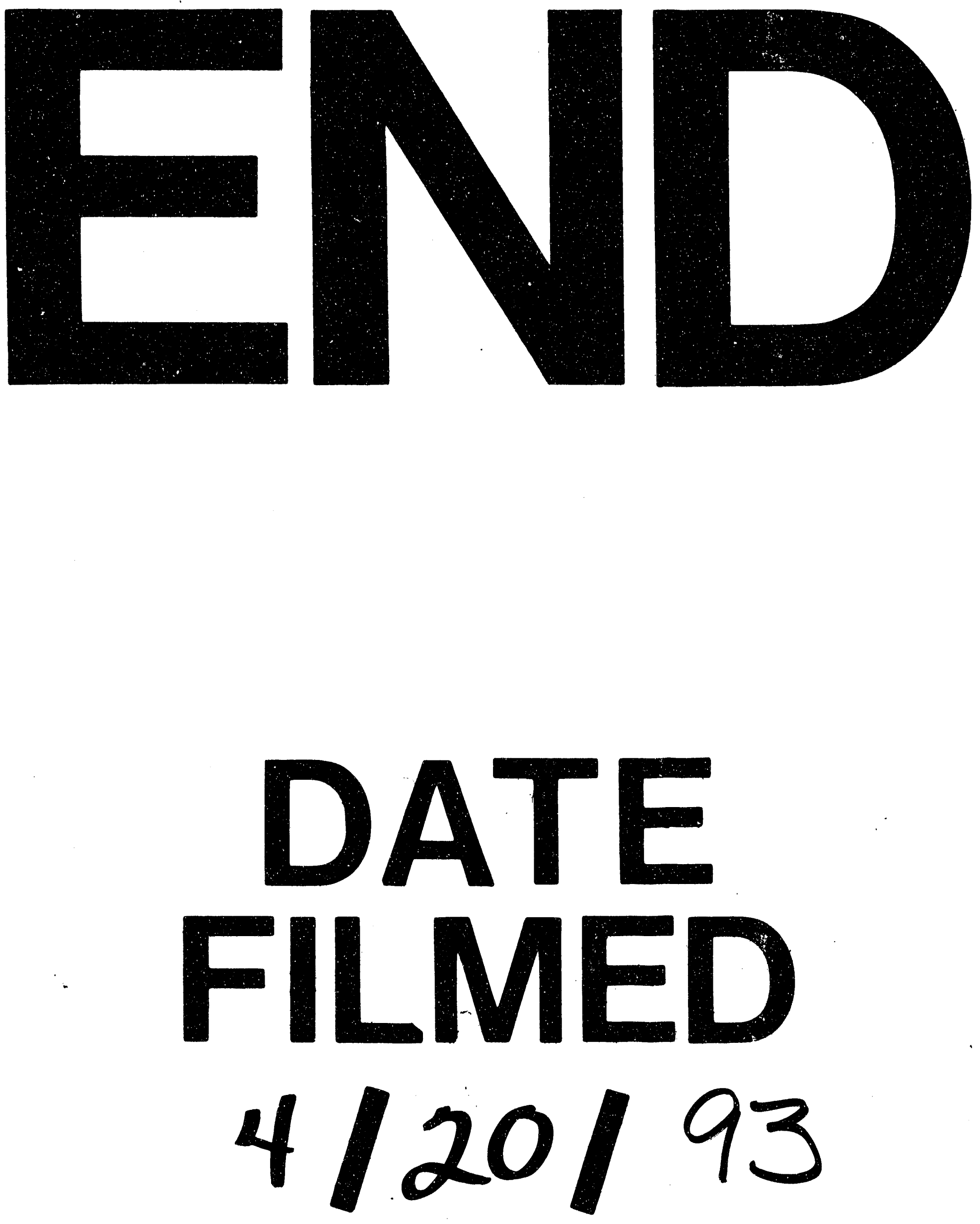

I 
